\title{
The Effect of Consumption On The Society Welfare In Sampang District
}

\author{
Syamsul Arifin*, Nur Aini Anisa, Siswohadi, Aisyah Darti Megasari, \& Abu Darim \\ Sekolah Tinggi Ilmu Ekonomi Pemuda Surabaya, Indonesia
}

\begin{abstract}
Welfare is one of the most important aspects in maintaining and fostering social and economic stability because it is necessary to minimize social jealousy in society. This study aims to analyze the effect of economicconsumption on the welfare of the societyin Sampang district. This research uses quantitative approach. This research conducted in Sampang District by using time series data and this research is analyzed by using linear regressiontechnique. According to the result of research indicate that consumption has significant positive effect onthe welfare of the society in Sampang district. Based on the results of research that has been conducted, consumptionsignificantly influence the welfare of the society in Sampang district.
\end{abstract}

Keywords: Consumption, Welfaresociety.

\section{Introduction}

National development is one of the efforts to establish a society that is fair, prosperous, competitive and prosperous. Various development activities have been implemented by the Indonesian government in regulating the economy as an effort to maintain the stability of the economy. One of the main indicators of the success of development is the welfare of society. Welfare is one of the important aspects to maintain and foster social and economic stability because this condition is needed to minimize the occurrence of social jealousy in society. The efforts undertaken by the government are related to maintaining economic stability in improving people's welfare through Human Development Index Mankiw (2006). Human development reports at both global, national and local levels that humancentered human development as the ultimate goal of development, not as part of development. (BPS, 2015).

Sampang is one of the districts located in the island of Madura which has the potential of a wealth of natural resources, such as the wealth of the sea, salt and oil mining, but in BPS data (2016), it is known that SampangDistrict is the highest district which suffer from poverty in East Java which ranks first with the highest percentage of poverty in East Java Province, which is $27.9 \%$ of the total population. Second and third order followed by Bangkalan and ProbolinggoDistricts respectively $24.7 \%$ and $22.2 \%$ respectively. While the area that has the lowest percentage of poverty is Batu City of $4.47 \%$ of the total population. This shows the high level of poverty in SampangDistrict has an impact on the low of community welfare in SampangDistrict.

High welfare is influenced by the consumption of society which is closely related to income, According to the Keynes of the classical economy states that consumption expenditures depend on income, the higher the income of a person the higher the consumption of the output. Thus, the high incomes of society are able to fulfill their needs and that means also improving the welfare. As the study by Wagle (2007), stating that income and consumption are simple variables that determine welfare, because both individually and households can be used to achieve human well-being, Revenue and consumption tend to be highly related to each other because consumption comes from income and income is very important for consumption. This is in accordance with research conducted by Gan (2013) which states that consumption is an activity using goods and services to reduce or spend the value of a good for the purpose of

\footnotetext{
* Corresponding author.

E-mail address: syamsularifin.stiepemuda@gmail.com (Syamsul Arifin)
} 
meeting the needs of everyday life, which the consumption of which shows the welfare of a person. In the welfare indicators of BPS (2016) consumption is one indicator of the welfare of the community, where the consumption of the people in view of the consumption of food and non-food. If the level of consumption for non-food is higher than the consumption of food, it can be said that the welfare of the people of the area increases. According to BPS (2016), the proportion of expenditure in Sampang District for food tends to remain within the same range. The proportion of household consumption of food and non-food is still balanced. It demonstrates that most household expenditures are used to meet basic needs (food consumption).Based on the thought, empirical study, and research gap that was found, then this research aim to be able to analyze whether or not "Influence Consumption on Social Welfare in SampangDistrict".

\section{Review of Literature}

\subsection{Consumption}

Consumption is one of the important things to analyze the economic condition in the long term and in the short term. According to (Soejoto, 2011) is the total amount of consumption expenditures incurred by the economy as a whole, where expenditures for consumption depend on the income of the people concerned.

According to Samuelson (2004: 125) household consumption is an expenditure for the purchase of goods and services that are useful to obtain satisfaction and meet the needs, the level of consumption provides a picture of the level of prosperity of a person or family. Therefore, it can be seen that household consumption does not stop at a certain stage, but always increased to reach the point of satisfaction and highest prosperity to feel prosperous. According to Mankiw (2006: 446), he stated that consumption is all expenditure that is spent in the form of food, clothing, streets and that is used in the needs of day-to-day or household needs. Michael (2001: 51) explained that the level of consumption provides a picture of the level of prosperity of a person or society. It means that the higher the level of one's consumption means the more prosperous the person is, otherwise the lower the level of one's consumption means the more unprosperous he is.Consumption is generally defined as the use of goods and services directly to meet human needs. Keynes in (Case \& Fair, 146: 2002) suggested that consumption is a positive function of income and highincome households, where more income is increasingly consumed, and high income households consume less food of low-income households because household income with large incomes is allocated to non-food consumption.

Meanwhile, according to Rejekiningsih (2011), hestatee that consumption is a human activity in using goods or services to meet the needs in order to achieve maximum satisfaction from the combination of goods or services in use, the quality and quantity of goods consumed can describe the prosperity or welfare of the consumer.Meanwhile, according to BPS (2015), it classifies the type of consumption made by the community into two that is consumption in the form of food and non-food consumption. In detail the BPS is grouped into the following types of consumption.

Table 1. Grouping of Consumption Types by BPS

\begin{tabular}{|c|c|c|}
\hline & Food Consumption & Non-Food Consumption \\
\hline 1. & Grains & 1. Housing and household \\
\hline 2. & Bulbs & facility \\
\hline 3. & Fish & 2. Goods and service \\
\hline 4. & Meat & 3. Clothing, footwear, and \\
\hline 5. & Egg and Milk & headwear \\
\hline 6. & Vegetables & 4. Durable goods \\
\hline 7. & Nuts & 5. Tax and insurance \\
\hline 8. & Fruits & 6. Party and ceremony needs \\
\hline 9. & Oils and fats & \\
\hline 10. & Beverages & \\
\hline 11. & Seasoning & \\
\hline 12. & Other consumptions & \\
\hline 13. & Ready food and drinks & \\
\hline 14. & Tobacco andbetel vine & \\
\hline
\end{tabular}




\subsection{Welfare}

Every human being has a desire for prosperity, prosperity demonstrates a state ofaffairs or a human condition, in which the people are in a state of prosperity, health, and peace. According to Law No. 11 of 2009. Social welfare is the condition of the fulfillment of the material, spiritual, and social needs of citizens in order to live worthy and capable of self-development, in order to carry out its social function.

According to the Welfare theory (In Todaro: 2006) that social welfare is positively associated with per capita income, but negatively associated with poverty and inequality. Where in this theory is illustrated through the welfare formula as is: $\mathrm{W}=\mathrm{W}(\mathrm{Y}, \mathrm{I}, \mathrm{P})$. Explanation of the formula is: Where $\mathrm{Y}$ is the per capita income and is positively related to the welfare function. Meanwhile according to Zulhanafi, et.al. (2013). The community can be called prosperous if the community has been able to meet its own needs independently (Suliswanto, 2010). The problems faced by many countries that concern the welfare of society are the inability of the community in fulfilling their life needs. World Bank (2000) summarizes community welfare indicators as an indicator of economic development, particularly human development and poverty. The formulation of economic development indicators is referred to as the Millennium Development Goals (MDGs).

\section{Methodology}

This study was conducted through a type of research with a quantitative approach. This research uses correlation method to find the influence between independent variable (consumption) (X1 to dependent variable) that is society prosperity (Y). Population in this research isSampangDistrict society from the total consumption of the community in the form of food and non-food and the welfare of the people seen from the human development index. Which is used is the secondary data of SampangDistrict which has a low level of community welfare. Sample in this research, consumption is seen from the total consumption of good people in the form of food and non-food in 2006-2015 while the welfare of the community is seen from thehuman development (IPM) in 2006-2015. Sampling within 10 years is able to describe the economy in SampangDistrict.

Data collection method used in this research is documentation. Because the data used are secondary data taken from the Central Statistics Agency of East Java Province. The data analysis method used is linier regression analysis.

\section{Result and discussion}

The analysis of this research uses linier regression analysis that serves to determine whether or not there is an influence between consumption of people's welfare. The regression equation obtained in this study is as follows: $\mathrm{Y}=$ $52.777+0.008 \mathrm{X} 3+$ e. From the equation it can be explained: 1). Constant value of 52.777 states that if the Consumer variable (X1) is given or fixed, the public welfare (Y) is 52.777. 2). The coefficient of consumption regression (X1) is 0.008 meaning that any changes in consumption variables (X1) will have a positive effect on the welfare of society as much as 0.008 .

The value of positive regression coefficient shows that the effect of one variable of consumption (X1) has an effect on the increase of society welfare by 0.008 . In the result of the partial significance test $(t$ test $)$ is used to find out whether the variable of independent variables such as consumption has an effect on the dependent variable that is the welfare of the people obtained the table 1 .

From result of significance test based on table 1, it shows that consumption level variable (X1) with probability is equal to 0,015 because probability at variable level of consumption $<0,05$ hence hypothesis that is "there is influence significant between level of consumption to welfare" is accepted $\beta$. Thus, it can be concluded that the level of consumption has an influence on the welfare of the community in SampangDistrict. This study is in accordance with research that has been done by Moav (2008) which stated that the consumption consumed by the people of London in a citizens do a lot of consumption and the level of welfare of the community increases. This is in line with the research that has been done by Mayer and Sullivan (2002) stated that conceptually and economically data 
consumption is more appropriate used to measure welfare compared with income data because consumption data is a more direct measure of welfare.

They statement is supported by research that has been done by Gradin (2008) which stated in his research that the low level of consumption by the public affects the poverty which means also affect the level of welfare of the community. While the research conducted by (Erwin: 2011) stated that household expenditures for consumption affect the significance of the welfare where when the household expenditure for consumption has increased the welfare also participate increased. But this research is not in line with the research that has been done by Hoirunnisa (2001) which the results of her research mention that the consumption variable has a negative value meaning it does not affect the value of human development index (HDI) which means also does not affect the welfare of the community.

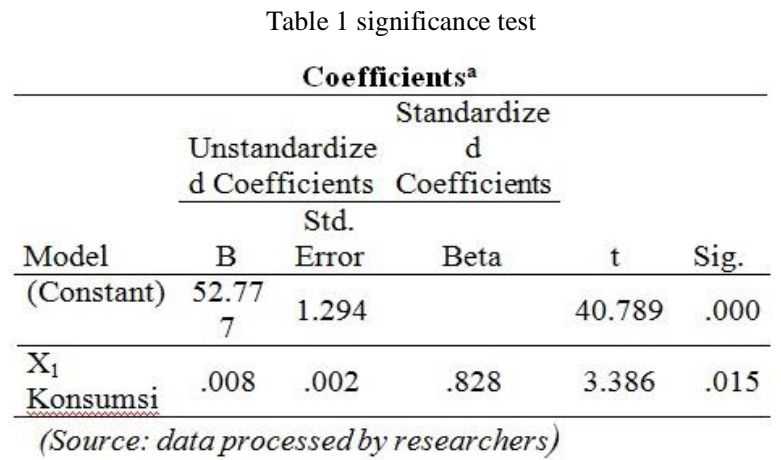

Consumption in SampangDistrict in 2006-2015 continues to increase, the increase in public consumption occurs in non-food consumption. Most people increase consumption to follow lifestyles such as clothing styles, gadget use and follow their prestige. Food consumption tends to stagnate from year to year. They assume that by consuming high non-food, they feel high social level. The increase in consumption is also followed by the increase of community welfare in SampangDistrict.

Based on the results of research and theory above, it can be said that consumption has an influence on the welfare of society. This consumption indicates the prosperity condition of a region, because if the level of consumption of a region is high it can indicate that the level of welfare is also high. With this hypothesis, consumption which is thought to have an influence on the welfare of the people of SampangDistrictis accepted and proven true.

\section{Conclusion}

There is a significant positive effect of consumption on the welfare of the people of SampangDistrict. Positive signification value on consumption variable shows that consumption has influence which is in line with society welfare, which means that thehigher society consumption of SampangDistrict, the higher the society prosperity in SampangDistrict will be.

It is expected that the citizen of SampangDistrict can consume rationally which consumption is not only fulfilling the needs but also can be profitable, one of them is to open a small business by utilizing the natural otential in Sampang District.

\section{References}

Anand, S., \& Sen, A. (2000). The income component of the human development index. Journal of human development, 1(1), 83-106.

BPS. (2015). Indeks Pembangunan masyarakat Kabupten Sampang. 
Case, K,.\& Fair, R. (2002). Principle of Economic. Jakarta: Prenhalindo.

Erwin Ndakularak. (2011). Analisis faktor-faktor yang mempengaruhi kesejahteraan masyarakat Kabupten/kota di Provinsi Bali. Jurnal Ekonomi dan Bisnis, 4(6).

Jhingan. (2010). Ekonomi pembangunan dan perencanaan. Jakarta: Rajawali Press.

Gan, Li. (2013). The chellenge of high inequality in china, Inequality in Focus, 1(2), 1-27.

Gradin, C., Canto, O., \& Del Rio, C. (2008). Inequality, poverty and mobility: Choosing income or consumption as welfare indicators. investigaciones económicas, 32(2), 169-200.

Ghozali, Imam. (2009). Aplikasi analisis multivariate dengan program IBM SPSS 19. Semarang: Universitas Diponegoro.

Hurd, Michael, Rohwedder.,\& Susana. (2000). income and consumption based poverty measures. National Bureau of Economic Research, 1-34.

Mankiw, N. Gregory. (2000). Makro ekonomi. $6^{\text {th }}$ Edition, Jakarta: Erlangga.

Meyer, B. D., \& Sullivan, J. X. (2002). Measuring Levels and Changes in Well-Being for the Poor Using Income and Consumption. Northwestern University Working Paper.

Michael, J. (2001). Pembangunan ekonomi di dunia ketiga. Jakarta: Glora Aksara Pratama.

Midgley, James. (1995). Social Development: The Developmental Perspective in Social Welfare. London: SAGE Publications Ltd.

Moav, Omer. (2008). Conspicous Consumptions, Human, Capital and Poverty. JEL, 1(2), 1-13.

Nicholls \&Sediaoetama. (2000). Konsumsi masyarakat daerah. Jakarta: BalaiPustaka.

Neculaesei, A. N. (2015). About Welfare in Cultural Context. SEA-Practical Application of Science, 3(07), 407-413.

Samoelson, Paul. (2004). Mikro Ekonomi. Jakarta: Erlangga.

Singh, R. (2012). Human development index and poverty linkages. International Journals of Marketing and Technology, 2(5), 219-230.

Soejoto, Adi. (2011). Teori ekonomi makro. Unesa University Press: Surabaya.

Suliswanto, M. S. W. (2010). Pengaruh Produk Domestik Bruto (PDB) dan Indeks Pembangunan Manusia (IPM) terhadap Angka Kemiskinan di Indonesia. Jurnal Ekonomi Pembangunan, 8(2), 357-366.

Todaro, M., Smith, C. S. (2006). Ekonomi pembangunan. Jakarta: Erlangga.

Undang-undang No 11 tahun. (2009). Tentang Kesejahteraan Sosial.

Wagle, U. R. (2007). Poverty in Kathmandu: What do subjective and objective economic welfare concepts suggest?. The Journal of Economic Inequality, 5(1), 73-95.

World Bank. (2000). World development indicators.http://www. World bankorg./.

Rejekiningsih, T. W. (2011). Identifikasi faktor penyebab kemiskinan di Kota Semarang dari Dimensi Kultural. Jurnal Ekonomi Pembangunan, 12(1), 28-44.

Zulhanafi, M. E., Aimon, H., \& Syofyan, E. (2013). Analisis faktor-faktor yang mempengaruhi produktivitas dan tingkat pengangguran di Indonesia. Jurnal kajian ekonomi, 2(03). 